\title{
Rевевки автісі: Technological gap in adoption of recommended sericulture cultivation practices
}

K. N. Manohar, R. B. Belli, S. H. Gotyal and S. S. Chavan

Article Chronicle : Received : 12.07.2020;

Revised:

29.09.2020;

Accepted :

17.10.2020

KeY WoRDS :

Technological gap,

Adoption,

Recommended,

Sericulture cultivation

practices
Author for correspondence :

\section{K.N. Manohar}

Department of

Agricultural Extension

Education, College of

Agriculture (UASD),

Vijayapur (Karnataka)

India

Email: manoharkn77@

gmail.com

See end of the article for

authors' affiliations
SUMMARY : The study was conducted in Vijayapur and Bagalkote districts of Northern Karnataka in 2019-20, which comes under non-traditional areas of sericulture. The sample size selected was 120 and the study revealed that 40.00 per cent of sericulture farmers belonged to high technological gap category. The major contributors in technological gap of sericulture production technology were soil $\mathrm{pH}$ management, disease control measures and chawki silkworm rearing methods. Keeping those above constraints to consideration the suitable policy implications by the government and with the suitable extension strategies it may be reduced and helped to improve sericulture status.

How to cite this article : Manohar, K.N., Belli, R.B., Gotyal, S.H. and Chavan, S.S. (2020). Technological gap in adoption of recommended sericulture cultivation practices. Agric. Update, 15(4): 336-339; DOI : 10.15740/ HAS/AU/15.4/336-339. Copyright@2020: Hind Agri-Horticultural Society. 